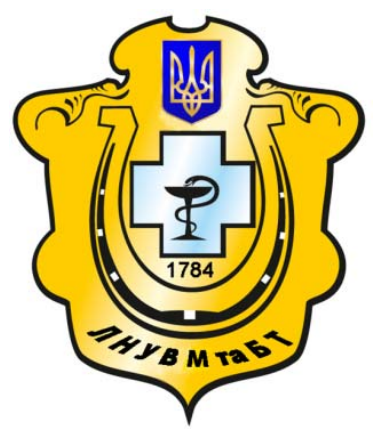

Науковий вісник Львівського національного університету ветеринарної медицини та біотехнологій імені С.3. Гжицького

Scientific Messenger of Lviv National University of Veterinary Medicine and Biotechnologies named after S.Z. Gzhytskyj

doi:10.15421/nvlvet7735

ISSN 2518-7554 print

ISSN 2518-1327 online

$\underline{\text { http://nvlvet.com.ua/ }}$

\title{
УДК 619:616-006:59
}

\section{Органна локалізація пухлин у дрібних тварин різних видів}

\author{
Н.І. Михайленко, Д.В. Войцехович \\ pathological_anatomy@nubip.edu.ua \\ Національний університет біоресурсів і природокористування Украӥни, \\ вул. Героїв Оборони, 11, м. Київ, 03041, Украӥна
}

\begin{abstract}
Вивчення робіт численних авторів показує значну варіабельність органної локалізачії пухлин у різних видів тварин. Було проаналізовано 135 випадків новоутворень різної локалізації. Серед тварин, в яких відмічали новоутворення, були собаки, коти, шури, мурчаки, піщанки, хом'яки, зайщі, кролі та плазуни. Найбільшу частку склали собаки та коти. Середній вік хворих собак із новоутвореннями був близько 8 років, котів - близько 9. Кількість собак, у яких новоутворення реєстрували до року, була значно меншою, ніж котів. Рівень виявлення пухлин у собак залишався однаково високим протягом всього життя, а у котів поступово зростав до 10 років та був максимальним у 13 років. Показано, щзо незалежно від виду дрібних тварин, щзо утримуються мешканиями Києва, найбільший відсоток пухлин припадає на шкіру та молочну залозу. У собак пухлини шкіри - на першому місиі, тимчасом як у котів та гризунів на першому місці є новоутворення молочної залози. Частими у собак були новоутворення сім'яників, тимчасом як у котів ию патологію не реєстрували. У собак та гризунів новоутворення яєчників мали суттєвий відсоток, у котів пухлини яєчників поступились новоутворенням кишки. У собак та котів майже на одному рівні реєстрували новоутворення, що локалізувались у ротовій порожнині. Крім перерахованих, відмічали пухлини матки, селезінки, нирки, легень, очей та їхні похідних тощо. Але частота їх виявлення склала менш ніж 3\% випадків. Особливості органної локалізаиії новоутворень є важливим для розуміння природи пухлин.

Ключові слова: ветеринарна онкологія, локалізачія пухлин, новоутворення шкіри, новоутворення молочної залози, соба-

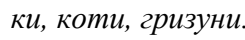

\section{Органная локализация опухолей у мелких животных разных видов}

\author{
Н.И. Михайленко, Д.В. Войцехович \\ pathological_anatomy@nubip.edu.ua \\ Наииональный университет биоресурсов и природопользования Украины, \\ ул. Героев Обороны, 11, Киев, 03041, Украина
}

\begin{abstract}
Изучение работ многочисленных авторов показывает значительную вариабельность органной локализации опухолей у разных видов животных. Были проанализированы 135 случаев новообразований различной локализации. Среди животных, у которых отмечали новообразования, были собаки, кочки, крысы, морские свинки, песчанки, хомяки, зайцы, кролики и пресмыкаюшиеся. Наибольшую долю составили собаки и кошки. Средний возраст больных собак с новообразованиями был около 8 лет, кошек - около 9. Количество собак, у которых новообразования регистрировали до года, было значительно меньшим, чем котов. Уровень выявления опухолей у собак оставался одинаково высоким в течение всей жизни, а у котов постепенно рос до 10 лет и был максимальным в 13 лет. Показано, что независимо от вида мелких животных, содержашихся жителями Киева, наибольший процент опухолей приходится на кожу и молочную железу. У собак опухоли кожи на первом месте, тогда как у котов и грызунов на первом месте находятся новообразования молочной железы. Частыми у собак были новообразования семенников, тогда как у котов эту патологию не регистрировали. У собак и грызунов новообразования яичников имели значительный процент, у котов опухоли яичников уступили новообразованиям кишечника. У собак и котов практически на одном уровне регистрировали новообразования, которые локализировались в ротовой полости. Кроме перечисленных, отмечали опухоли матки, селезенки, почек, легких, глаз, их производных и другие. Но частота
\end{abstract}

Mykhalenko, N.I., Voitsekhovych, D.V. (2017). Organ tumor in small animals of different species. Scientific Messenger LNUVMBT named after S.Z. Gzhytskyj, 19(77), 162-165. 
их выявления составила меньще 3\% случаев. Особенности органной локализачии новообразований важны для понимания природы опухолей.

Ключевые слова: ветеринарная онкология, локализация опухолей, новообразования кожи, новообразования молочной железы, собаки, кошки, грызуны.

\title{
Organ tumor in small animals of different species
}

\author{
N.I. Mykhalenko, D.V. Voitsekhovych \\ pathological_anatomy@nubip.edu.ua \\ National University of life and environmental sciences of Ukraine, \\ Heroyiv Oborony Str., 11, Kyiv, 03041, Ukraine
}

The study shows works of numerous authors considerable variability organ localization of tumors in different animal species. 135 cases of neoplasms of different localization were analyzed. Among the animals that had tumors, there were dogs, cats, rats, guinea pigs, gerbils, hamsters, hares, rabbits and reptiles. The largest proportion were dogs and cats. The average age of dogs with neoplasms ranged about 8 years, cats - about 9. The number of dogs with neoplasms up to a year was less than that of cats. The level of detection of tumors in dogs remained equally high throughout life, and in cats gradually grew to 10 years and was a maximum of 13 years. It is shown that irrespective of the type of small animals kept by the inhabitants of Kiev, the greatest percentage of tumors falls on the skin and the mammary gland. In dogs, skin tumors are placed in the first place, while in cats and rodents, neoplasms of the mammary gland are on the first place. Frequent in dogs were neoplasms of testes, whereas in cats this pathology was not recorded. In dogs and rodents ovarian tumors had a significant percentage. Ovarian tumors in cats giving place colon tumors. In dogs and cats almost at the same level recorded tumors localized in the mouth. In addition to these noted a tumor of the uterus, spleen, kidneys, lungs, eyes and more. But the frequency of detection was less than 3\% of cases. Features of organ localization of tumors is important for understanding the tumors nature.

Key words: veterinary oncology, tumor localization, skin tumors, mammary tumors, dogs, cats, rodents.

\section{Вступ}

Важливим ендогенним фактором ризику виникнення пухлин $є$ вік тварин: факт підвищення захворюваності з віком добре і давно відомий (de las Mulas and Reymundo, 2000). Щодо вікового діапазону діагностування, то пухлини у тварин можуть виявлятися упродовж усього їхнього життя, навіть на першому його році (Kessler and von Bomhard, 1997), проте найбільша частка хворих тварин спостерігається у віці 7-12 років. Тут дані різних авторів суттєво не різняться i залежно від величини вибірки середній вік хворої тварини варіює мало $(9,6-10,5$ років) (Orlova and Terehov, 1969; Baranov, 1991; de las Mulas and Reymundo, 2000; Mysak et al., 2004; Shestiaieva, 2015).

Вивчення робіт численних авторів показує значну варіабельність органної локалізації пухлин у різних видів тварин і деякі закономірності ураження того чи іншого органу в окремих видів тварин. Якщо порівняти статистичні дані різних авторів стосовно пухлин собак, можна бачити досить великі відмінності в частоті органної локалізації пухлин. За даними ряду дослідників, у собак найбільшу питому вагу в структурі загальної онкопатології мають пухлини молочних залоз, які складають, за узагальненими даними, до 48\% - 52\% від усіх пухлин (Orlova and Terehov, 1969; Baranov, 1991; Junters et al., 2000; Gorman, 2003). Водночас є свідчення, що пухлини молочних залоз собак займають другу, а може, і нижчу, позицію після новоутворень шкіри та слизових оболонок, підшкірної клітковини, м'яких тканин (Rostami et al., 1994; Chekhun and Mazurkevych, 2001). За цими даними, вони виявляються у 10-20\% випадків серед усіх пухлин різної локалізації, тимчасом як пухлини шкіри, наприклад, у 29-45\% (Bastianello, 1983; Mysak et al., 2004). В історичному огляді поодиноких робіт, дато- ваних періодом з кінця XIX до 70-х років XX століття, наведені дані, що частіше, ніж пухлини молочних залоз, у собак спостерігалися злоякісні пухлини легень та печінки або кишечнику та сечостатевих органів (Shishkov and Burba, 1977).

Схожі закономірності органної локалізації відмічають і у котів. Пухлини молочної залози займають у них переважно третє місце, поступаючись лімфомам та неоплазмам шкіри (Rostami et al., 1994; de las Mulas and Reymundo, 2000).

Є відмінність в органної локалізації і у дрібних гризунів. У мишей спостерігають переважне ураження пухлинами молочної залози, тимчасом як у щурів молочна залоза є місцем появи доброякісних пухлин і зрідка злоякісних. Пухлини матки майже не реєструються у мишей та доволі часто спостерігаються у щурів. Як у мишей, так і у щурів майже не відмічають пухлини шлунка та інших відділів органів травлення.

Варто наголосити, що порівняння даних частоти виявлення пухлин у домашніх тварин може бути не зовсім адекватне, оскільки у багатьох випадках тварин із пухлинами умертвляють без подальшої верифікації новоутворень. Узагальнення статистичних даних для дрібних тварин утруднюється досить суперечливими вихідними даними. Це зумовлено насамперед тим, що автори будують аналіз лише на клінічному або секційному матеріалі, нерідко на основі невеликої вибірки, без урахування чисельності собак у регіоні, характеру розподілу їх за статтю, віком, породою, умовами утримання або проживання тощо. В Україні такі дослідження не проводяться, хоча вивчення регіонарних особливостей розповсюдження злоякісних пухлин у тварин є цінним матеріалом для з'ясування деяких аспектів епідеміології злоякісних пухлин людини. Зважаючи на це, метою нашої роботи стало визначення особливостей органної локалізації ново- 
утворень у дрібних тварин, що реєструвались в різних клініках ветеринарної медицини міста Києва.

\section{Матеріал і методи досліджень}

Для аналізу використовувався матеріал, який надходив до кафедри патологічної анатомії НУБіП України для гістологічного дослідження від різних клінік ветеринарної медицини міста Києва за 2016 рік.

\section{Результати та їх обговорення}

Було проаналізовано 135 випадків новоутворень різної локалізації. Серед тварин, що страждали на пухлини, були собаки, коти, щури, мурчаки, піщанки, хом'яки, зайці, кролі та плазуни (рис. 1).
На першому місці - собаки, які склали 60,7\% від усіх випадків, за ними йдуть коти - 26,7\%, щури $5,9 \%$, мурчаки - 2,2\% та пісчанки - 1,5\%. Інші тварини складали менше ніж 1\%. Такі види тварин цілком відповідають вподобанням мешканців міста Києва. Припускаємо, що з часом такий розподіл може змінитись, оскільки з'являється все більше видів тварин, яких люди тримають у своїх квартирах.

Середній вік хворих собак із новоутвореннями був близько 8 років, котів - близько 9. Цікаво те, що кількість собак, у яких новоутворення реєстрували до року та в рік, була значно меншою, ніж у котів. Проте надалі рівень виявлення пухлин у собак залишався однаково високим протягом всього життя, а у котів поступово зростав до 10 років та був максимальним у 13 років (рис. 2 ).

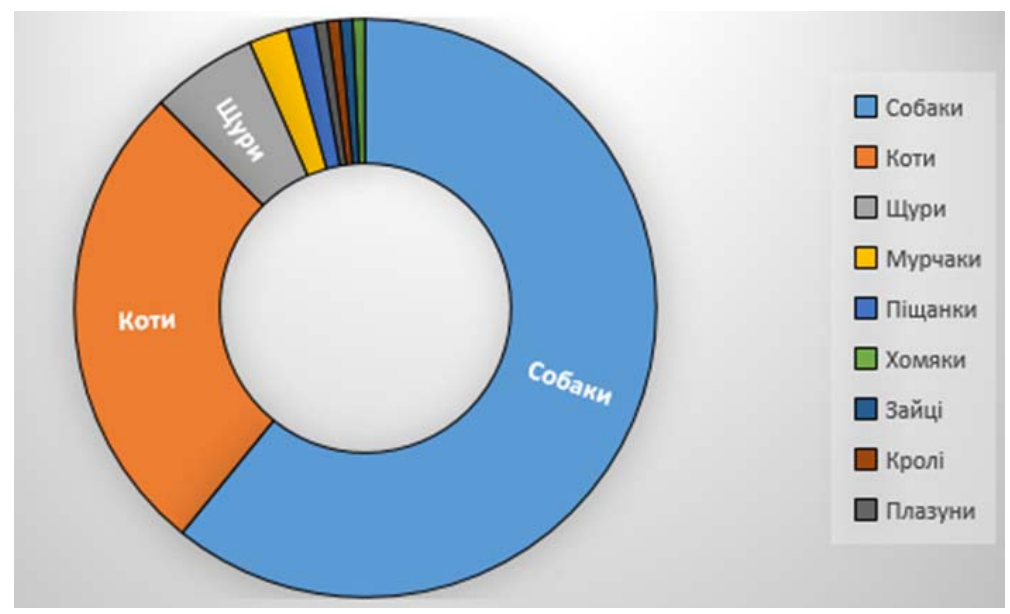

Рис. 1. Розподіл випадків за видами тварин

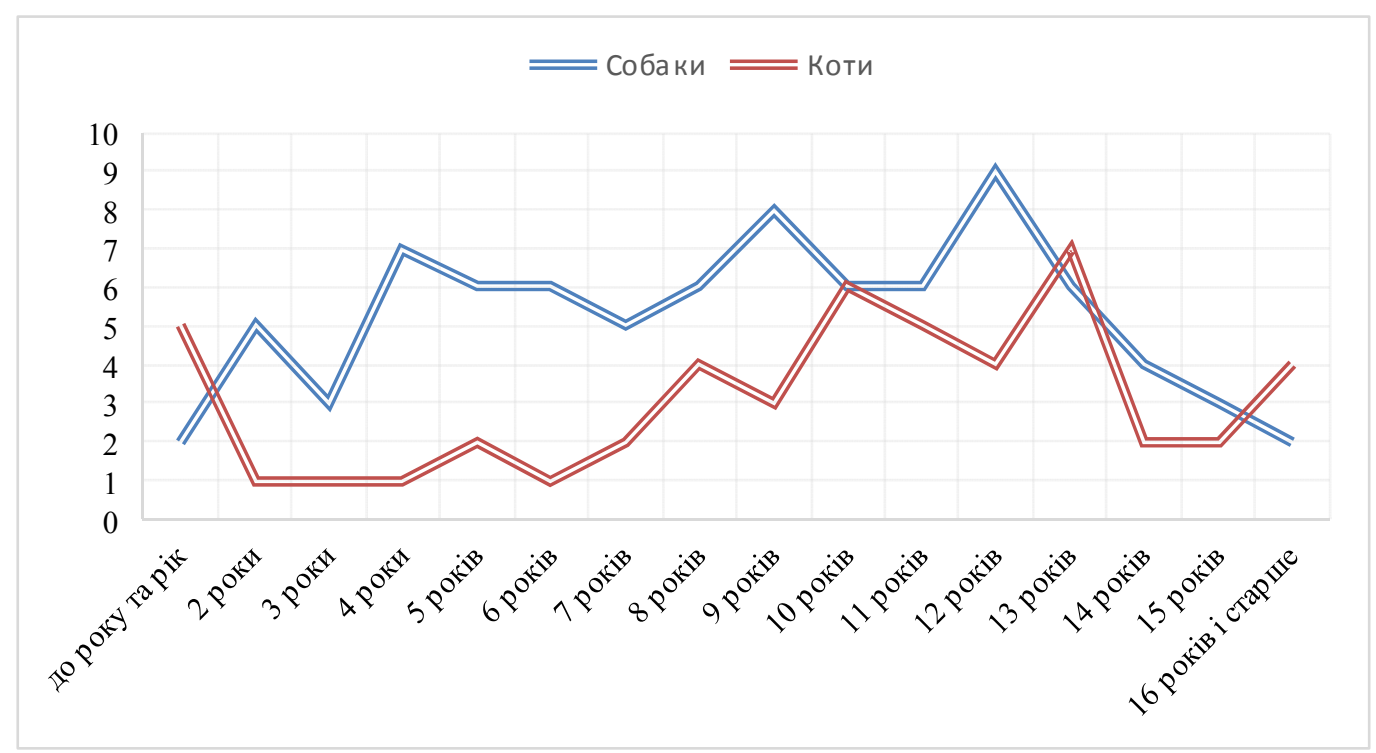

Рис. 2. Вік хворих собак та котів

В подальшому при аналізі органної локалізації пухлин щури, мурчаки, піщанки, хом'яки, зайці та кролі були об'єднані в одну групу - гризуни. Перші місця в рейтингу найпоширеніших місць локалізації ново- утворень зайняли пухлини шкіри та молочної залози 3 однією лише різницею - у собак пухлини шкіри виявилися на першому місці, тимчасом як у котів та гризунів на першому місці $є$ новоутворення молочної 
залози (рис. 3). У подальшому вже спостерігається суттєва відмінність в органній локалізації пухлин між видами тварин. На третьому місці за розповсюдженістю у собак - новоутворення сім'яників. При цьому в даній виборці пухлин сім'яників у котів та гризунів взагалі не виявлялося. Також у собак часто діагностували новоутворення яєчників. У гризунів новоутворення яєчників та матки теж мали суттєвий відсоток. А ось у котів пухлини яєчників та матки поступились новоутворенням кишки. У собак та котів майже на одному рівні реєстрували новоутворення, що локалізувались у ротовій порожнині. Крім перерахованих, відмічали пухлини селезінки, нирки, легень, очей та їхніх похідних тощо. Але частота їх виявлення склала менш ніж 3\% випадків та через малу вибірку вони не можуть бути враховані при визначенні закономірностей в органній локалізації пухлин у тварин різних видів.

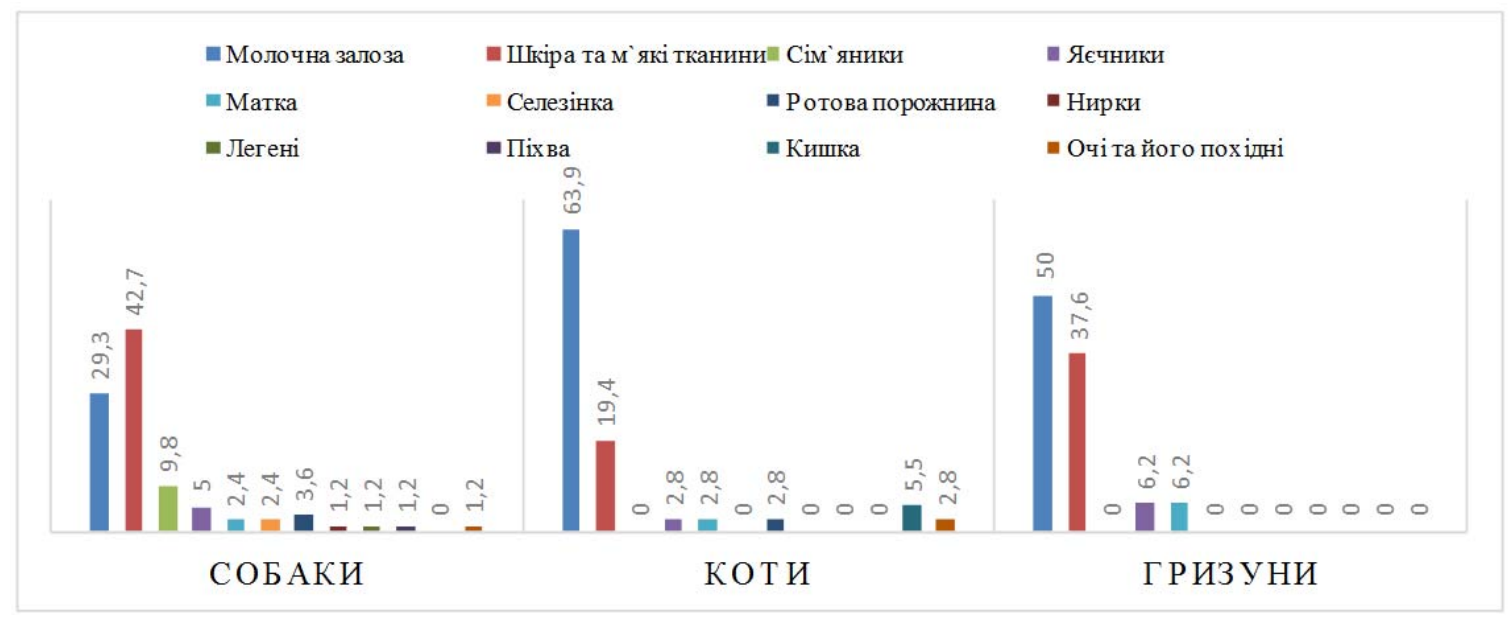

Рис. 3. Органна локалізація пухлин у різних видів тварин

\section{Висновки}

Таким чином, можна 3 упевненістю стверджувати, що незалежно від виду дрібних тварин, що утримуються мешканцями Києва, найбільший відсоток пухлин припадає на шкіру та молочну залозу. Частими у собак були новоутворення сім'яників, тимчасом як у котів цю патологію не реєстрували.

Перспективи подальших досліджень. Особливості органної локалізації є важливими для розуміння природи пухлин. Але свідчення про частоту їх виникнення недостатні або різнорідні, що утруднює вирішення ряду питань, зокрема, порівняльної онкології. Тому проведення досліджень 3 онкопатології тварин $\epsilon$ вельми актуальним та своєчасним.

\section{Бібліографічні посилання}

Martin de las Mulas, J., Reymundo, C. (2000). Animal models of human breast carcinoma: canine and feline neoplasms. Rev. Oncologia. 2(6), 274-281.

Kessler, M., von Bomhard, D. (1997). Small animal contribution to pediatric oncology. Berl. Munch. Tierarztl. Wochenschr. 110(9), 311-314.

Baranov, S.V. (1991). Diagnostika opuholey u sobak. Veterinariya. 6, 66-68 (in Russian).

Orlova, L.V., Terehov, P.F. (1969). Statisticheskie dannyie opuholevyih zabolevaniy u sobak v Moskve (1962-1966 gg.). Vopr. onkol. 4, 91-95 (in Russian).

Mysak, A.R., Shekel, V.F., Zaviriukha, V.Sh. (2004). Morfolohiia okremykh pukhlyn velykoi rohatoi khudoby ta sobak. Naukovyi visnyk Lvivskoi natsion. akademii vet. med. im. S.Z. Hzhytskoho. 6(1), 56-59 (in Ukrainian).

Shestiaieva, N.I. (2015). Termin vyzhyvannia sobak iz novoutvorenniamy molochnykh zaloz riznykh histolohichnykh typiv. Naukovyi visnyk LNUVMBT im. S.Z.Hzhytskoho. 17, 1(61), 2, 186-190 (in Ukrainian).

Gorman, N. (2003). Molochnyie zhelezyi. Onkologicheskie zabolevaniya melkih domashnih zhivotnyih. M.: Akvarium, 190-194 (in Russian).

Junters, P., Znidersic, L., Pogacnik, M. (2000). Epidemiology of tumor in a defined population of dogs. $11^{\text {th }}$ Ljudevit Jurak Inter. symp. on comparative pathology. Book of abstracts. Zagreb, Croatia.

Chekhun, V.F., Mazurkevych, A.I. (2001). Pukhlyny dribnykh sviiskykh tvaryn: klinika, diahnostyka, likuvannia (in Ukrainian).

Rostami, M., Tateyama, S., Uchida, K., Naitou, H., Yamaguchi, R., Otsuka, H. (1994). Tumors in domestic animals examined during a ten-year period (1980 to 1989) at Miyazaki University. J. Vet. Med. Sci. 56(2), 402-405.

Bastianello, S. (1983). A survey on neoplasia in domestic species over a 40-year period from 1935 to 1974 in the republic of South Africa. Vl. Tumors occurring in dogs. Onderstepoort J. Vet. Res. 50(3), 199-220.

Shishkov, V.P., Burba, L.G. (1977). Leykozyi i zlokachestvennyie opuholi zhivotnyih. M.: Kolos, 319-331 (in Russian).

Стаття надійшла до редакиії 1.02.2017 